\title{
Socialising place attachment: place, social memory and embodied affordances
}

\author{
CATHRINE DEGNEN*
}

\begin{abstract}
The significance of place attachment for later life has been convincingly demonstrated. Scholars have offered useful models that help account for the depth of feeling bound up in place attachment in later life, how this attachment is achieved, and its relevance for belonging and identity. To date, however, this focus has largely been on the individual level of experience. This article draws on sociological and anthropological perspectives to consider how place attachment is forged and experienced in dynamic interaction with other entities and other processes: how place attachment is also a collective, relational and embodied process, caught up and experienced via social memory practices and sensorial, bodily knowledge. This resonates with and contributes to the 'relational turn' which has attracted burgeoning interest in the larger home disciplines of sociology, human geography and anthropology, and reciprocally helps them extend and build their interaction with critical ageing studies. In making this argument, I draw on two periods of anthropological, ethnographic participant-observation that I conducted in a semi-rural village in the former coalfields in South Yorkshire, England.
\end{abstract}

KEY WORDS - place attachment, belonging, social memory, relational, embodied.

\section{Introduction}

Place attachment, or the emotional sense of deep connection with particular places that people experience, is a significant source of meaning throughout the lifecourse. Its particular salience in later life has been argued for by authors writing from a wide variety of disciplinary perspectives. Important lessons come from this body of work, offering as it does models that help account for the depth of feeling bound up in place attachment in later life, how this attachment is achieved, how it is sustained and

* School of Geography, Politics and Sociology, Newcastle University, UK. 
how it varies. However, as I shall be arguing here, the existing place attachment literature focuses largely on how individual people experience and make sense of place. What is less evident in the literature is a consideration of how place attachment is forged and experienced in dynamic interaction with other entities and other processes: how place attachment is also a collective, relational and embodied process, caught up and experienced via social memory practices and via embodied, sensorial registers. In placing the emphasis here instead on bodily and collective memories, I draw on two periods of anthropological, ethnographic participant-observation that I conducted in Dodworth, a semi-rural village in the former coalfields in South Yorkshire, England, with people in their sixties, seventies, eighties and nineties about their experiences of growing older.

In anthropology and sociology, relations to and through place have often been encompassed within the wider concept and point of concern with 'belonging' (Benson and Jackson 2013). These disciplines have been adept at demonstrating the social and cultural dynamics of the ways in which place, identity and belonging are made and reproduced through social practices and processes, operating both on individual and collective levels, as well as with and through embodied relations with the world (see e.g. Basso 1996; Cohen 1982; Edwards 2000; Gordillo 2004; Savage, Bagnall and Longhurst 2005; Stewart 1996). Anthropology and sociology, however, have not been attentive to the particular dynamics of place and belonging in regards to ageing and later life (although for an important exception, see Phillipson 2007). This article seeks to address that gap by bringing perspectives from anthropology and sociology to bear on the debates in ageing studies over place attachment. In particular, my aim is to begin thinking through the ways in which place attachment is bound up in social memory, embodied knowledge and the significance of the passage of time. In so doing, I seek to open up the conversation across disciplines in order to contribute to the development of critical ageing studies' perspectives on place attachment itself as a lived reality.

My argument here is that place attachment in later life can be fruitfully understood as situated within the concatenation - the series of interconnected things - of place, belonging, social memory, embodied subjectivity and everyday experiences ( $c f$. Blokland 2001; Misztal 2003; Stewart 1996). As I will show, such a perspective highlights the profoundly connective, collective social processes in which place attachment operates in people's lives. It also demonstrates the sensual and embodied relationships people have with place. Closer consideration of social memory, the embodied sensorial register of experience and the sharing of these memories and experiences via everyday talk in turn help enrich and deepen our understanding of place attachment. 
This article examines these points in a twofold way: firstly, it develops a consideration of the affordances of place. By this I mean the ways in which place is habitually sensed and manoeuvred through and around, becoming 'sedimented' in a habituated body. This, I argue, contributes to fostering place attachment. Secondly, I shall elaborate through ethnographic examples how place attachment does not only operate at the level of the individual. Instead, it is also the profoundly social, collective ways of sharing, discussing and debating memories of place that I experienced time and again during my fieldwork that make (and break) senses of belonging and place attachment. Indeed, it is precisely the intersection of these two elements where bodily subjectivity, embodied knowledge, individual and shared memory come together, that I argue is what makes place attachment so relevant for building a sense of belonging and identity. In making these arguments, my work resonates with recent points put forward to attend to the 'relational turn' and the turn to affect (see e.g. Andrews, Evans and Wiles 2013), which have attracted burgeoning interest in the larger home disciplines of sociology, human geography and anthropology, and helps them extend and build their interaction with critical ageing studies.

\section{Connecting place attachment with critical perspectives on belonging and social memory}

\section{Place attachment and later life}

There is a wide range of scholarly perspectives on place attachment in later life. This includes environmental gerontologists such as Lawton (1983, 1985 , 1986), concerned primarily with person-environment relations from a behaviouralist and psychological perspective; humanistic geographers like Rowles $\left(1978,198_{3} a, 198_{3} b\right)$, focusing on the creation of meaning, place and lived experience in later life; and critical ageing scholars, including Laws (1994, 1995, 1997), who have drawn attention to the spatialised dimensions of older age and the ways in which these are sociocultural constructions (McHugh 2006: 494). Place attachment in later life is credited with a number of positive attributes, including enhancing the quality of life, building a sense of belonging and buttressing personal identity (Gilleard, Hyde and Higgs 2007; Kellaher, Peace and Holland 2004; Peace et al. 2011; Rowles 1983b). Peace, Holland and Kellaher (2005: 200) make plain that quality of life is protected 'when the older person can adopt strategies that allow attachment or connection' to the environment. They argue that older people 'look for ways to reinforce and increase their points of attachment to place, finding and sometimes creating new options to enable them to do so' if these connections 'become 
compromised by decline in their own competence and/or the demand characteristics of environment' (2005: 200). Indeed, some authors have argued that it is precisely because place attachment is so essential for self, identity and belonging that place becomes ever-more crucially important in older age. This is because, it is suggested, older people are under a great deal of social pressure to maintain a coherent self in the face of social denigration, something which place attachment is said partly to mitigate against (Rubinstein and Parmelee 1992: 139-40).

Thus, much is at stake in place attachment in later life. This theme is evident in formative work in the field by Graham Rowles. He emphasises interconnections between place attachment, older age and personal identity. More particularly, he shows how it is that place attachment can facilitate and enhance the 'preservation of a sense of personal identity' as people age (Rowles $1983 \mathrm{~b}$ : 3oo, emphasis added), a point reiterated by authors such as Rubinstein and Parmelee (1992). They argue that place attachment helps older people maintain a sense of continuity as well as symbolise independence and social competence (1992: 140). Others, building from Rowles, have turned their attention to related issues such as how place attachment in older age need not be singular, but can also develop in multiple sites via seasonal migration (e.g. McHugh and Mings 1996) and how other factors such as immigration can mediate sense of place and identity in older age (Becker 2003).

An emphasis on interpretive, processual approaches to place attachment, such as the seminal piece by Rubinstein and Parmelee (1992) mentioned above, has been central in the literature on place attachment. Such work highlights the ways in which place attachment can happen at a multitude of levels of scale, such as attachment to the home space, a place of work and a neighbourhood (Rubinstein and Parmelee 1992: 142), as well as the highly variable nature of place attachment itself: it can be 'strong, weak, positive or negative, narrow, wide or diffuse' in its valence, as well as being built incrementally (1992: 143). The emphasis in this body of work has been on an individual bond with place: 'personal meaning in shaping sense of, and affective ties to, place' (1992: 146). This model of place attachment in older age emphasises 'issues of personal identity as central to attachment to place in later life' (1992: 159). The collective or social aspects of this bond are discussed only in terms of how 'the socially constructed life course (culturally defined standards for what constitutes a life course and its key events )' might intersect with those individual, personal levels of experience (1992: 148). What I wish to explore, however, and as I shall show below, is that relations with and through place are not only personal - they are also powerfully social.

Finally, place attachment is said to work in a variety of complex ways. Researchers have examined 'the gamut of processes operating when 
ageing individuals form affective, cognitive and behavioural ties' (Peace et al. 2011:136) to their physical environments. One of the longstanding contributors to this field, and referred to above, is Rowles' early work which still stands as a landmark publication in this regard. Rowles' concept of 'insideness' has been extensively drawn upon by many authors working on place attachment and later life to help account for research participants' sense of place attachment and identity. He describes three elements of insideness: physical insideness, social insideness and autobiographical insideness (Rowles 1983b: 302-8), arguing that these three forms of insideness work together to constitute place attachment.

Autobiographical insideness is of particular interest for the links it makes between place, identity and memory. Rowles explains that autobiographical insideness refers to the way in which people narrate their connection to place and build a sense of identity through the stories they tell about what has transpired through their lives in the sites and locales in their local environment. These sites Rowles calls 'incident places'. His description of incident places evokes how his research participants perceive place not just as it is in the present, but also as it is remembered, memories that are layered on to the physical and visible landscape (Rowles 1983b: 303 ). Whilst extremely useful for calling our attention to the role of memory and time in people's experiences of place, this perspective, like much of the work on place attachment, centres on the individual and the self.

But what if place attachment is also social and collective? Social parameters are by no means absent in the work of various researchers described in the paragraphs above, important work that seeks to understand the ways in which place attachment bonds individuals to place. However, I put forward here that what also still demands an accounting are the powerful ways in which place works not just to tie people as individuals to places, but that it also works to tie individuals to each other. It is this sense of sociality and collective bonding via place that was so dramatically present in Dodworth that I seek in the first instance to address in this paper. In so doing, firstly I draw inspiration from the literature on social memory which has enriched our understandings of the ways in which memory can be seen to work. Far from being a static, passive thing that resides in the individual, researchers have demonstrated how memory is both a form of ongoing practice and an aspect of social relationships (Lambek 1996: 298-9), deeply embedded in groups and social dynamics and being used at times as markers of social differentiation (Halbwachs 1925; Olick and Robbins 1998). Secondly, social memory is not only cognitive but is also often embodied with bodily practices able to 'sediment' meaning and memory in bodies (Connerton 1989: 72-3). This brings me to the second point that this paper puts forward: the deeply embodied, relational and sensuous elements of place attachment. 


\section{Place: relational and embodied perspectives}

'Place' itself is not a straightforward, homogenised concept, nor is it singular in either sense of the word - it occurs and is experienced in multiple ways, but it also occurs and is experienced in dynamic interaction with other entities (people, objects, ideas, other places). Cresswell (2009), for example, highlights how place is made through combination of materiality (roads, buildings, people, animals, commodities, waste, vehicles), meaning (spanning the spectrum from personal, individual, biographical to shared, social and communal) and practice (what people do in places in their everyday lives). He argues that these three factors work together and are linked (Cresswell 2009: 170) but are also continuously being negotiated and transformed (2009: 174). This renders place complexly multi-dimensional and relational as work in human geography has made evident (Massey 1994; Massumi 2002; Thrift 1999). Transposing these ideas on to research into ageing and place, it is apparent that, as Cutchin writes, 'recognition of the complexity and interconnectedness of places, their ongoing change, and the continuous (non-dualistic) and active relationship of people and places suggests a need for improved theory about aging in place' (2009: 443 ), such as in an earlier article by Cutchin himself (2003). This is a call which some geographers have recently take up (Andrews, Evans and Wiles 2013, Andrews et al. 2007, 2009) and which this article contributes to. Indeed, as Andrews, Evans and Wiles (2013) have recently highlighted, although 'space' and 'place' have been established concepts in the literature on ageing, they have tended to be represented as fixed and static categories, whereas in contrast, 'relational thinking evokes an image of spaces and places emerging not only in situ, but also through their connections' (Andrews, Evans and Wiles 2013: 1349) and through their relations with other sites and events. This is a model that emphasises change and shifts through time, a continually unfolding, embodied process of becoming and not a resolved and fixed essence of being.

Simultaneously, while humanistic geographers have focused their relational thinking on the networked layers of experience and meaning of space and place at various levels of scale, debates in anthropology over relationality, whilst still based in processual, dynamic frameworks, have instead emphasised the making of people and the making of relations between them, and how some connections are at times brought into focus and others screened out (Edwards 2000). The emphasis has been on social relations and connections, culturally and socially speaking. My aim here is to draw from and build on this newly invigorated geronotological geography by bringing in anthropological perspectives on belonging in order to take points of critical analysis from both to bear on the question of place 
attachment in later life. In particular, I would like to consider briefly the view from anthropology and sociology on belonging, identity and place.

\section{Belonging and place: the perspective from anthropology and sociology}

Anthropology and sociology have long been attuned to the importance of people's sense of belonging at the level of everyday, mundane, lived experience ( $c f$. Cohen 1982: 6). Key points of interest for understanding belonging have included its centrality for collective identity formation, but also the ways in which a sense of belonging for some can forge a sense of exclusion for others. Feeling as though one belongs, or that one is entitled to claim belonging, can be highly contextual and contingent. In a seminal text on English ideas of kinship in the village of Elmdon, Marilyn Strathern (1982) shows precisely how ideas of who 'belongs' to Elmdon are intertwined with kinship and place. Belonging to Elmdon is not just about living in Elmdon, but is also about being a member of one of the old village families. Writing about Strathern's work in Elmdon, Yarrow (2011) reminds us that whilst belonging in this case would thus seem written in biology (by virtue of descent and blood ties) and thus inflexible, Strathern demonstrates how kinship and belonging are more fluid than this. They can be reckoned in Elmdon by either emphasising maternal or paternal kinship connections. As such, 'belonging' comes to have highly social, changeable contours: 'in practice, who is included and who is excluded changes with context. Classification does not simply delimit predefined sociological groups but highlights the interests by which they feel themselves to be united or divided' (Yarrow 2011:89). Belonging is thus contested terrain, and not always straightforwardly positive. The social and cultural dynamics of belonging mean that whilst claims to belonging can appear to be fixed, in actual practice and lived experience, belonging is often contingent, strategic and at times divisive. Such a perspective brings considerable scope to the concept of place attachment which is premised to a large extent on an unproblematically positive and largely (though not wholly) individualised sense of belonging, as identified above. Instead, anthropological perspectives highlight the powerfully social aspects of the ways in which place can evoke a deeply emotive sense of connection that is also simultaneously sometimes a fragile one.

Also under fruitful scrutiny by anthropologists have been the ways in which social memory can be put to use in building a sense of belonging to a place and, conversely, 'how are places themselves constituted by the different ways in which people belong to them' (Edwards 1998: 148). What is of particular interest here for the argument I am putting forward about socialising place attachment are the ways in which 
the past presents people with a problem: what to select and what to ignore; what to emphasise and what to screen out. Stories about the past do not merely render visible a person's connections to persons and places, they make and break those connections ... belonging requires a selection of which elements to pick out, which social relationships to mark ... and which identities to promote. (Edwards 1998: $15^{\circ}$ )

To illustrate her point, Edwards relates an incident from her fieldwork in 'Alltown', a post-industrial town in the north of England. Two local men, Alltown born and bred, tell a fanciful tale to a newcomer about the history of the house the newcomer had just bought in the town. Edwards demonstrates how this incident can be seen as the two Alltowners staking a claim to being 'real' Alltowners, as being entitled to claim a deep connection to the place, as well as revealing the outsider (i.e. does not belong) status of the newcomer (1998: 153).

\section{Developing the concept of place attachment: embodied, sensual and social}

It is these insights I wish to bring to bear on the concept of place attachment in later life. For if, as the literature on place attachment has done, one assumes that place attachment is primarily an individual and personal dynamic, one that helps 'root' and 'stabilise' one's sense of self in a particular locale, and that this is then 'naturally' something that grows over the passage of time, then the social weight of how people, collectively, navigate larger social forces and pressures, becomes erased. And yet, as Edwards, Cohen, Strathern and many others' ethnographic research has shown, various elements of identity and belonging are mobilised to demonstrate connections to place.

Similarly, I propose that place attachment must also be understood as contextual and able to be strategically mobilised. Additionally, place attachment also resides in other forms of connection that link back to place, but which may not initially appear to be 'about' place. But through long-term, immersive, ethnographic fieldwork, one comes to appreciate how these forms are strategically mobilised in connection with place, and connect back to social memory. Attending to these profoundly social and cultural processes would give us a much more nuanced account of place attachment and how and why it becomes relevant in people's lives in a much richer, textured way.

Indeed, and as the ethnographic material I use in the next section of this paper will show, it is also the affordances of place, the ways in which they are habitually sensed, navigated and become lodged into bodily subjectivity that connects people to place. ${ }^{1}$ An extremely useful way of thinking about this is Seamon's notion of 'body-ballet' (1980). This is a term he developed, as a humanistic geographer seeking to evoke the ways in which 'the body moves 
habitually as it is performing some task such as driving, typing or cooking', and to show how 'places exhibit a kind of unchoreographed yet ordered practice that makes the place just as much as the place's more static and bounded qualities do'; that places come processually to have meaning via such bodily knowing and movement, both of which are individual and social (Cresswell 2009: 175). As Corsín Jiménez puts it, 'the world is not a known place that exists prior to our engagements with it. On the contrary, the world happens with us ... Through our engagements with and in the world, we become the spaces to which we have invested our practices' (2003: 141). It is this knowing of a place via deeply embodied, and yet social, forms that I now seek to elaborate on via the ethnographic data below. What I wish to consider is how place attachment can be perceived and understood via these lenses of sociality, bodily subjectivity and social memory. In turn, I also seek to address what such a step can help us better understand about how a deep connection with place is made, sustained, and what it achieves in the lives of the older people I worked with in Dodworth.

\section{The research setting and methodological reflections}

This article draws on research I conducted in 2000-2001 and 2003-2004 during two periods of ethnographic fieldwork totalling 26 months in a village in the north of England. During this time, I conducted ethnographic participant-observation fieldwork, wrote extensive field note diaries and conducted $6_{3}$ in-depth semi-structured interviews for two different projects. ${ }^{2}$ Located near Barnsley, South Yorkshire, Dodworth is a village of about 5 ,ooo people. This is a region that for nearly 200 years was heavily industrialised, with coal and steel providing the main forms of male employment up until the early 199os. Up until the early 199os, coal was still being mined on a large scale in and around Dodworth. This ended abruptly with the mass closure of coal mines across Britain in the 199os, the conclusion of a tumultuous battle between the Conservative government and the National Union of Miners. The demise of mining has meant the loss of a deeply significant source of employment, but also a centrally important source of identity and social organisation, transforming Dodworth beyond recognition on multiple levels of everyday experience. Within a decade, the area went from being modestly prosperous to requiring European Union Objective 1 funding as one of Europe's poorest areas. This then is a field site where people have been coming to terms with great social stakes of rupture, transformation and social exclusion over a number of years.

My research focuses on the everyday experiences of my research participants. As such, this paper draws on research that in the initial stages was 
conducted in public meeting places for older people in Dodworth, such as the series of community centres run by the local council in the village which held weekly tea and bingo meetings, a local luncheon club that met once a week, the local Senior Citizen's Association, and Monday night bingo held at the Dodworth Social Club. These public settings meant that I was able to become familiar with a large number of older village residents over a period of time, and for them to get to know me. As fieldwork progressed, I spent increasingly more time in private settings with individual people I had come to know, accompanying them in their everyday activities and spending time visiting with them at home and in their daily activities.

The research methodology I used meant that I spent a great deal of time every week visiting with people I came to know over the course of the research, both as individuals but also in group settings. Membership of these groups varied, but some people went to more than one, and group membership overlapped in many cases. This meant that I was able to meet and chat with people sometimes every couple of days, and at least once a week. As time passed, I gradually built up a network of friends and contacts and became increasingly invited to partake in other aspects of people's lives, outside these public spheres. As the months of fieldwork continued, I carried on attending the public meeting places, but I also visited people in their homes and partook in their daily lives with them. This meant that I was immersed in the everyday flow of conversation and social interaction with a wide variety of people and in multiple social contexts.

Dodworth is a place of intense localism marked by a density of overlapping social networks. These networks include those of kinship, work, friendship, neighbours and school mates, both historically and in the present day. Dodworth and its neighbouring villages are relatively small with complicated and long-standing webs of relations that knit many (but not all) people together in multiple ways. Many of the people I came to know were long-term Dodworth residents and, consequently, can recall intimate details about each others' lives over a long period of time. Such details are used regularly in everyday public and private conversation to place each other and to discuss both contemporary and historical events. As I came to learn, shared memories of the past are 'put to work' by the older residents I came to know in Dodworth (Degnen 2005, 2012), used to navigate contemporary social relations. As I will show below, social memories are also deeply imbricated with sense of place and embodied subjectivity.

\section{An embodied and sensuous place attachment}

During my fieldwork in Dodworth, I was introduced to Gloria by a mutual acquaintance on the grounds that Gloria had lived as a younger woman 
in the same row of terrace houses that I was living in at the time. Gloria, then in her early nineties, became a close friend. It transpired that not only had she lived on the same row of houses as I did, she had actually lived in the exact same house as I did. This was during the Second World War whilst her husband was away in the forces. On many occasions, we would chat about that particular part of the village, and she would tell me stories about who else had lived there and what her life had been like seven decades before. Gloria wanted to tell me about the history of 'our' house and who had lived in it after her, and before me. Here is one example from a taped interview I conducted with her:

Mrs Sowerby had your house. She [first] lived in ... those [houses] on the bottom [row of terraced houses next to Holdroyd's Yard] ... but the woman that lived next door to her, she objected to [the Sowerbys] coming past her window and they had to go up those few steps - I don't know if they are still there? - to get into the Yard, from the bottom [row of] houses. And anyway, this woman started putting things for Mrs Sowerby to fall over and that sort of thing. So Mrs Sowerby was glad to move into that end house that you have [on the upper row].

When speaking of Mrs Sowerby's misadventures with a neighbour who wanted to prevent her from using the right of way that passed by the window, Gloria is casting back many decades into the past. And yet despite the passage of time, 'those few steps' that Gloria remembers were ones that were lodged deeply into her account of that place. I remember being startled by hearing this small but important detail in her story, as those steps were indeed still there. They had become part of my own daily experience of the effort required to navigate through and around densely packed Victorian-era housing. It was this parallel in our experiences that first made me start to think about the ways in which embodied knowing might figure into the bodily relationships that people build with place. Such an embodied knowing, however, can only accumulate through the passage of time and via repeated navigation of intimate and daily spaces and routines how the stone steps feel underfoot, how they are dangerously slippery when wet, how sometimes the extra effort to get up or down them is a nuisance. It is this sensual inhabiting of place, the 'body-ballet' (Seamon 1980) of intimate embodied knowing of places that demand accounting in regards to place attachment. The body matters in the deep emotional connections that people come to have for and with place. The difference between my experiences and hers, however, is that Gloria could contextualise her knowledge within a much longer temporal frame, one that enabled her to compare the 'then' with the 'now'. What Gloria's example also forces us to consider are the ways in which place gets woven into our emotional registers of way-faring in and through our daily lives - the material realities of place that become familiar, become 'known' and, consequently, become 
part of our subjectivity itself. Such experiential and subjective moments are bound up in everyday, mundane minutiae of daily life, emerging only as small clues in casual conversation, and need careful attention to discern and detect.

Further examples of this embodied knowing of place that forges an attachment, a bond, with place comes from a series of interactions I had with many people about a book of historical photographs of the village called Honest Dodworth 2 (Hamby and Wyatt 1997). Many, if not most, people I came to know owned a copy of this book which had been compiled by two men in the village and published with a local publishing house in the late 1990 . The photos in Honest Dodworth date from the late 18 oos through the 195 os. During earlier stages of my fieldwork, when I was making the transition from public to more private arenas of social life, the book was almost invariably produced as something I should see if I wanted to learn about Dodworth and its history. People had many stories of the places and individuals pictured in the book, and these would pour forth when we looked at the pictures together. As such, Honest Dodworth reveals on a number of fronts the ways in which place attachment through time and in the face of historical and social change is made manifest in the lives of the people I worked with. It helped also make me aware of the regular style of discourse about people and places that occurred frequently in Dodworth. One example of this from many comes from the conversation I had with Vera and Gladys about a picture in Honest Dodworth. They were friends in their eighties. Both had both grown up in Dodworth. We were talking about the picture of the Old Vicarage (Figure 1).

Author: And what about the Vicarage?

Vera: That's the Old Vicarage there.

Gladys: $\quad I$ used to wash steps there.

Author: $\quad$ You did?

Gladys: At Saturday morning for five pence and my lunch, and I used to have to do a set of steps against the gate, and then steps half way up, them steps there, more steps around here at the side and some at the back. For, uh, five pence and me lunch and I used to think: 'I wish she'd give me six pence and not bother with lunch!'. A bun [and] ... a glass of lemonade, too, and she used to stand there while I was having it and I used to wish she'd go, you know.

Vera: (suddenly interjecting) That was Old Mr Barker's wife.

Author: Was that the vicar's wife?

Vera: Her husband, Old Mr Barker...

Gladys: Aye, uh.

Vera: We were only little when he were there.

Gladys: Well, well it were his daughter, Mary that used to stand there [watching over me whilst I ate]. 


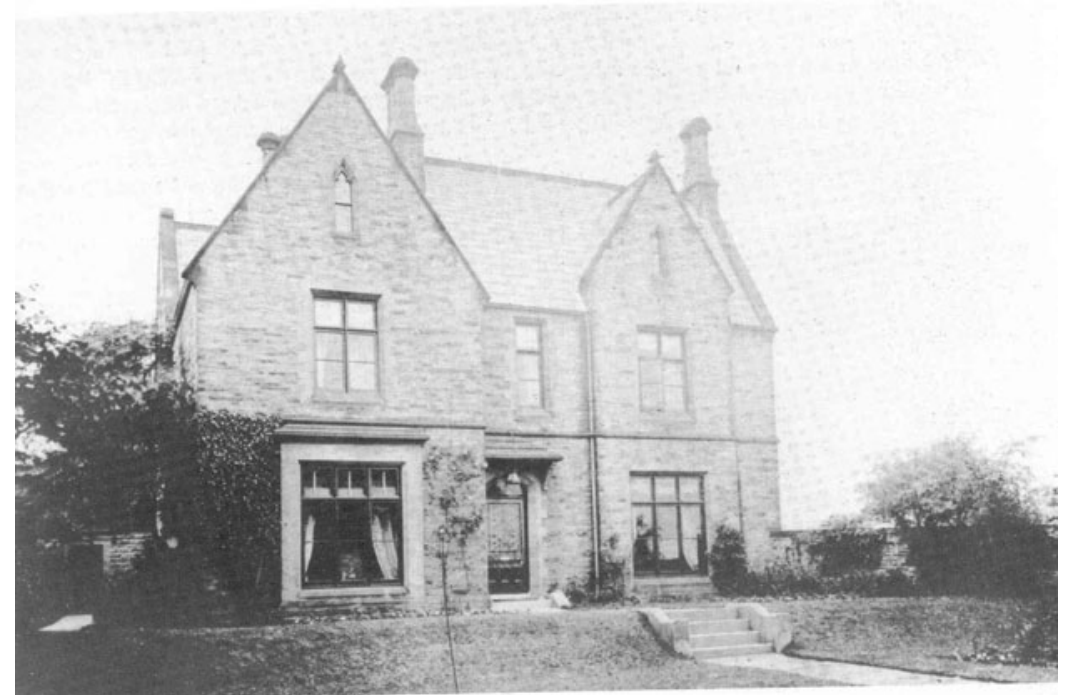

Figure 1. The Old Vicarage. Reproduced from Honest Dodworth 2 (Hamby and Wyatt 1997: 25).
Vera: (agreeing) Yes, Mary. He was an old man ... he were, he was still parson, weren't he, when he were in his eighties?
Gladys: Aye, but you couldn't tell what he were saying because he'd no teeth, either, had he?

Evident in this extract is the sociality of memory, which I will return to below. But for my purposes here, it is the ways in which Gladys's account of the Old Vicarage is bound up in sensorial, embodied memories that I wish to draw attention to. Seeing the façade of the Old Vicarage triggered for her a series of memories about people and place. Whilst recounting about the steps, Gladys also points out those that are visible in the photo and all the others that are not. It was the bodily memory of all those steps, etched into her memory many years ago over multiple occasions of hard physical work that stood out, as well as the discomfort of eating her lunch as a young girl whilst being scrutinised by her employer, the vicar's daughter. Also standing out for her is the aural memory of Old $\mathrm{Mr}$ Barker's voice, impeded by his lack of teeth. All of these details, known and registered in the body, are also details that afford Gladys a way of relating to place that stakes a claim to being connected to the Old Vicarage, but in turn to the history and places of Dodworth itself.

Whilst pictures from Honest Dodworth often provoked narrative accounts such as this, the older village residents I came to know who had lived their lives in Dodworth would often recount similar stories in casual 
conversation. Marg, in her mid-eighties for example, told me on many occasions about how, when she was a teenager living in Dodworth, she used to work 'in service' for a wealthier family. They lived on the other side of a small valley from Dodworth. She would walk across several fields and up the hill to their house from her family home in Dodworth. Important details in this story that she always included were the walk across those fields, the steepness of the hill and being able to hear her neighbour Mrs Hart's distinctive voice shouting 'Forrester!!!!', the name of her son, calling him in for his tea as Marg would walk home for hers. This acoustic detail of her story is embedded into specific details about the location of the various houses (the Harts, the house Marg was in service at and her own home near the Harts back in Dodworth) and the topography of the hill. But in recounting this story, she also performs and demonstrates a deep, temporally rich connection to the hill, the road, the houses and the people who had lived there when she was younger, as well as reflecting on the transformations that have occurred since that time. This, I argue, is an example of place attachment in action and embodied in the senses.

One notable characteristic of all of these narrative examples is the extent to which memories can be physical, with very specific, embodied details embedded in the memories themselves. For example, two speakers mention steps: 'there used to be two steps down into the shop' and 'they had to go up those few steps, I don't know if they are still there, to get into the yard'. In other examples from my fieldwork, people would refer to other physical elements of the villagescape, such as Mavis looking at an old picture of her street and pointing out the trees visible in the shot, saying: 'those poplar trees, you had to go past them to get into my house'. As such, the trees become landmarks in navigating one's way through place. But they are also indicative of one's relationship with and intimate bodily knowledge of place. The unconscious inclusion of such detail in everyday stories stems from the profound familiarity people come to have with their surroundings. This ranges from the everydayness of climbing up and down those steps, the way the verticality of the steps interrupts a flat place and forces the body to move slightly differently, the kinaesthetic activity required by the steps or the feeling of the cold stone - but so too how they then tie into the social and into the connections and disconnections between people living there. It is not a coincidence, I argue, that so many names of people long gone are evoked in these narrative accounts (Mrs Sowerby, Mrs Hart, Forrester, Old Mr Barker, Mary Barker). This is indicative of the extent to which places and people are inextricably linked through and by each other. The narrators of these stories are also staking a claim to belonging to this particular place by their ability to tell such stories. This ability in turn is predicated in no small part by embodied knowledge. As 
Bennett, citing Back (2009) reminds us, 'places are more than social constructions or imaginaries and more than a context for social relations; places are also material and engage with all the senses and with physical bodies' (2014: 660). It is this deeply sensual, embodied relationship with place that is so evident in these accounts, and which adds something highly pertinent to our understanding of place attachment.

\section{The social bonds of memory and place attachment}

As is evident from the examples above, places in Dodworth mattered. Local places were evoked regularly in casual conversation. Over time, patterns began to emerge in my fieldwork data about how people talked about local sites. I focus in this section on three aspects of this talk about place, and what it can elucidate for enriching understandings of place attachment. I shall begin with a conversation I had with Mavis and Betty one summer's day.

Mavis had become a close friend and I saw her often; Betty was her neighbour, but the two women had recently rekindled their acquaintance, having known each other since school days. Both women were widowed and in their early eighties when I knew them, and both were life-long village residents. On the particular day in question, I had gone for a cup of tea with Mavis, and Betty popped in to say hello. Our conversation moved through various topics such as Mavis' new settee that is more comfortable for 'old folks' as it is higher from the floor than her previous one; whether or not the new local chiropodist was any good; and various other bits of local gossip. At one point, conversation settled on the new substantial building that was being erected on the High Street, just around the corner from where we were sitting. Mavis recounted several of the rumours she had heard about what it might be. At first everyone was saying it was going to be an old folks home, Mavis told us, but now, she said, she had heard from Alice that they are building a new post office and a chemist. Betty then mentioned a terrace house down that way that had recently been sold, indicating which one she meant by using the name of the family that had lived there a number of decades ago. She asked Mavis if she remembered the shops that used to be by it, the one where... but before she could finish her sentence, Mavis interjected '... where they used to charge batteries!'

Both women became very animated, excitedly recounting who used to own which shops in the village during their childhood and through their adult lives ('Sally Fearn's clothing shop and the second one down was a sweet and ice cream shop'), describing various events that had occurred 
in the locales, and naming people, both deceased and still alive, detailing their connections to these places and to each other. Their conversation moved them through the village landscape whilst still seated in Mavis' front room, simultaneously spanning and compressing a number of decades of experience. The stories they shared and swapped about places and people included buildings and people that were both still present in the village and others that had been long knocked down or deceased, the two women working their way in their conversation up and down the village landscape and through time.

A second example comes from one of the regular tea and bingo sessions for older Dodworth residents at a community centre in Dodworth. These sessions were attended by a group of about 20 women and men every Tuesday afternoon for about two hours. Centre members would attend every week, gathering early to secure their preferred seat, chat and mingle. There would be a bingo session and then a tea and biscuit break, followed by another session of bingo. The tea breaks were very social and often the focal point for much village conversation and gossip. At this particular tea break, the name of an old Dodworther, Howard Walker, came up. Howard was someone it seemed who had moved away but recently had returned, knocking on doors and speaking to people as a converted Jehovah's Witness. The return of Howard, and his changed religious affiliation, set conversation in the room alight. Mavis, Beryl and Tom, sitting closest to me, began talking in depth about Howard as both Tom and Mavis had had a knock on their door from Howard during the week. So startled by Howard's appearance had Tom been that he had brought to the centre with him (for the express purpose of showing other members) a studio picture of himself and Howard that they had had taken together in Barnsley in 1939. 'We were mates', Tom explained to me. The picture and Howard's sudden reappearance sparked an intense and highly detailed discussion amongst Mavis, Beryl and Tom as to who exactly Howard was related to in Dodworth. This included which branch of the Walker family, which school he had attended and in which years, and if he was the brother or cousin of Percy who lived at 1 Oldroyd's Row, a terrace of houses in the village. Mavis turned to me at that point in the conversation and said 'you know, just down from where you're living'. Tom corrected this detail, saying that no, it was Gelder Row, not Oldroyd's Row, that Howard had lived on. Such detail mattered.

In some respects, these vignettes are clearly examples of what Rowles calls 'incident places', mentioned earlier. Incident places are where significant and memorable life events have occurred in the locale and which in turn help bond people to place. Such incident places incrementally accrue over time, becoming part of each individual's autobiography. In turn, 
each individual becomes 'more and more a part of the place to the point where it has become an extension of self' (Rowles $1983 b$ : 303 ). But what is evident here is that individuals are only part of the story of how place attachment builds and is experienced.

I propose that in order to account fully for what is transpiring in interactions such as this one, we need to attend to the social and collective parameters of people's relationships with place. The conversational vignette between Mavis and Betty demonstrates the ways in which place attachment is made manifest on everyday levels of experience. It also underlines the ways in which a sense of belonging and place are woven through seemingly mundane conversations. Their conversation attests to the emotional sense of deep connection to and with particular village locales - their conversation is an example of place attachment as it operates in daily life. The depth of feeling is evidenced by the timbre of the conversation and the enthusiasm with which talking about various sites in Dodworth mattered to both women and animated them. Secondly, their expression of place attachment in this conversation is one conducted in the register of sociality and conviviality. It is not incidental that Mavis and Betty were talking about various places in Dodworth, but rather, and precisely the point that I wish to underline here, that this was talk that was done together and not simply as individuals. Another example is that of Gladys and the Old Vicarage, above. Mention of one person's former home or a local shop no longer present sparked mention of others nearby, mental chains of memory and place that are activated in conversation, together. Place attachment, the emotional sense of deep connection to and with place, thus is enhanced and sustained in this context by such social conviviality, a conviviality which in turn serves as a point of mutual connection between the women.

Furthermore, the conviviality promoted by this shared place attachment is premised on both women's ability to remember and share memories of the places and people that used to inhabit the village. Knowledge and experience of village places, some now profoundly transformed yet still 'seen' by Mavis and Betty as they used to be, serve as a point of mutual connection. They connect both women not to just any place, but to this place, to this village, to these streets and to each other. In the case of the group discussion about Howard's reappearance, contemporary events are woven immediately into place and into social memories. But so too do my interlocutors seek to bring me into the frame ('you know, just down from where you're living') across time and space despite my lack of direct experience of Howard. This speaks both to the temporal depth of place attachment as it plays out in the everyday, but also to the work of sociality and conviviality that these social practices linking place, belonging and memory can achieve. 
Social memory is thus deeply pertinent here. Place attachment in this collective, social and historical sense amongst my research participants is underpinned by social memories - shared, collective accounts of place, people and events that span many decades of life as lived in this particular part of the world. This is not a simple form of reminiscence in which narrators passively recount events from the past; it is an active, dynamic, animated and profoundly social practice in which the exchange of stories and memories binds people together and creates (for some) a sense of belonging. The earlier example of the Old Vicarage is again relevant here, as Vera and Gladys remind each other of the chronology and temporal framing of events and characters from the village's past whom they both remember, checking and correcting details with each other (was it Old Man Barker's wife or daughter? And was he in his eighties?).

It is in these ways that we can see how memory is a 'privileged area for the examination of the link between the individual and the social' (Bloch 1992: 3) - shared memories of people and of places (both of which are often inextricably intertwined, as the examples above demonstrate) are used to fashion and maintain social relations. The sharing of memories in this highly social way is also imbricated in building a deep sense of attachment and of belonging to place. Thus, an important aspect of situating oneself temporally and in relation to others is accomplished through social memory practices, which have the power to create a sense of continuity and solidarity within social groups (Fentress and Wickham 1992: xi). Place attachment in this deeply social sense 'works' when one's interlocutors share similar experiences and feelings about local places. But an important caveat is that not everyone in Dodworth had access to these experiences, having perhaps retired to the village but not lived there over several decades (Degnen 2013). The importance of this shared dimension is demonstrated by Karen's story to me about taking her grandchildren, born in the late 199os, on walks up into the fields surrounding Dodworth. The traces of a previously thriving industry have become invisible to the untrained eye, with railways that once transported coal now transformed into gravel paths for bike riding, horse riding and walking; the pit heads knocked down and overgrown with brambles and saplings; and the towering spoil heaps now covered with grass and scrub. Karen tells her grandchildren about all of these things and what they used to look like, tries to point out to them where these things used to be, where Levitt Pit was. But, as she tells me, 'Cathrine, they can hardly imagine it. They can hardly believe that there was a pit there. They sigh about "oh, not another story, Nana!" and "yes, yes, we know that's where you used to play and that's where so and so's shop used to be", but I think they are a bit fed up of hearing about it' because it means little to them, as it is so 
far out of their realm of experience. Place attachment accrues through time and through personal experience, but it also connects people when they are able to share memories and sense of attachment, something here that does not work in this particular case across the generational divide.

\section{Conclusions}

In this article, I have taken up a recurring theme in the literature on ageing and place, namely place attachment and what bonds people and place in later life. The existing literature makes a strong case for the ways in which place attachment fosters a sense of identity and belonging. As perspectives from anthropology and sociology remind us, however, 'belonging is a messy and uncertain process fractured along a range of axes and social fields' (Benson 2014: 3110). Who we are and how we come to feel connected to place is something I have sought to explore here in terms of experiential everyday social relations. I have argued in this article that new insights can be gleaned by considering embodied, sensorial knowledge and social memory practices with experiences of place in older age. This reframing permits us to deepen conceptions of place attachment and also opens new space within existing debates over experiences of place and of ageing.

In particular, I have argued that the literature to date has not always captured the profoundly social aspects of place. It is not just that people are exposed to place (see Phillips, Walford and Hockey 2011: 74, describing how place attachment is particularly relevant in older age due to the length of 'exposure' to a place), but rather how one's history and those of others become bound $u p$ in place and the embodied spatiality. Place attachment is not reducible to an individual's experience but instead comes to be made and remade in animated, active forms of social memory and contemporary exchange and debate amongst friends, relatives, neighbours and acquaintances.

Perspectives from anthropology and sociology help us to see how it is that a sense of connection and bond with place is not something that stops at the boundaries of the individual. Rather, it is put to work in socially powerful ways via social memory practices. Social memory, however, is polysemic, and multiple meanings can be read on to the past (Olick and Robbins 1998: 127). Memory is prone to 'strategic remembering and deliberate forgetting' (Melion and Küchler 1991: 30), and this forgetting can be accomplished in ritualised forms, but also 'in small everyday acts' (Carsten 1995: 331 ). Memories are thus used and are worked to fashion a sense of continuity, of belonging and of self; memory is at once a personal and collective endeavour, a site of negotiation and positionality. 
These lessons from the literature on social memory, when brought into conversation with place attachment, permit us to enlarge the range of possibilities in how place, belonging and identity can be understood to operate that both exceed and inform individual experiences as well as re-emphasise the contextual and fluid character of place, identity, memory and belonging. Secondly, social memory, like knowledge, is often embodied and bodily practice can 'sediment' meaning and memory in bodies (Connerton 1989: 72-3). I have, in this article, examined the ways in which place attachment operates at an embodied and sensual level of experience. It is my position that, whilst the body has not been absent from the accounts linking place and older age (see e.g. Kearns and Andrews 2005; Kontos 2004, 2005), how embodiment and the affective components of place are imbricated at the level of everyday experiences of older age has not yet been sufficiently explored and that this, too, requires attention in order to enrich our understanding of how place attachment works in the world.

\section{NOTES}

1 I am grateful to the anonymous peer reviewer of a previous and separate journal article submission who helped me begin to think through and articulate this point.

2 The first period of research was on the experiences of ageing, selfhood, social transformation and social memory; the second was on public understandings of genetically modified food; these periods of fieldwork were supplemented by continuous residence in Dodworth until 2005 and regular visits since that time. In Degnen 2012, I present a fully detailed ethnographic description of this locale.

\section{References}

Andrews, G., Cutchin, M., McCracken, K., Phillips, D. and Wiles, J. 2007. Geographical geronotology: the constitution of a discipline. Social Science and Medicine, 65, 1, $15^{1-68 .}$

Andrews, G., Evans, J. and Wiles, J. 2013. Re-spacing and re-placing geronotology: relationality and affect. Ageing $\mathcal{E}$ Society, 33, 8, 1339-73.

Andrews, G., Milligan, C., Phillips, D. and Skinner, M. 2009. Geographical gerontology: mapping a disciplinary intersection. Geography Compass, 3, 5, 1641-59.

Back, L. 2009. Researching community and its moral projects. 2 I st Century Society: Journal of the Academy of Social Sciences, 4, 2, 201-14.

Basso, K. 1996. Wisdom Sits in Places: Landscape and Language Among the Western Apache. University of New Mexico Press, Albuquerque, New Mexico.

Becker, G. 2003. Meanings of place and displacement in three groups of older immigrants. Journal of Aging Studies, 17, 2, 1 29-49. 
Bennett, J. 2014. Gifted places: the inalienable nature of belonging in place. Environment and Planning D: Society and Space, 32, 4, 658-71.

Benson, M. 2014. Trajectories of middle-class belonging: the dynamics of place attachment and classed identities. Urban Studies, 51, 14, 3097-1 12.

Benson, M. and Jackson, E. 2013. Place-making and place maintenance: performativity, place and belonging among the middle classes. Sociology, 47, 4, 793-8o9.

Bloch, M. 1992. Internal and external memory: different ways of being in history. Suomen Antropologi, 1 7, 1, 3-15.

Blokland, T. 2001. Bricks, mortar, memories: neighbourhood and networks in collective acts of remembering. International Journal of Urban and Regional Research, 25, 2, 268-83.

Carsten, J. 1995. The politics of forgetting: migration, kinship and memory on the periphery of the southeast Asian state. Journal of the Royal Anthropological Institute (N.S.), 1, 2, 317-35.

Cohen, A. 1982. Belonging: the experience of culture. In Cohen, A. (ed.), Belonging: Identity and Social Organisation in British Rural Communities. Manchester University Press, Manchester, UK, 1-20.

Connerton, P. 1989. How Societies Remember. Cambridge University Press, Cambridge.

Corsín Jiménez, A. 2003. On space as a capacity. Journal of the Royal Anthropological Institute, 9, 1, 137-53.

Cresswell, T. 2009. Place. In Thrift, N. and Kitchen, R. (eds), International Encyclopedia of Human Geography. Volume 8, Elsevier, Oxford, 169-77.

Cutchin, M. 20og. Geographical gerontology: new contributions and spaces for development. The Gerontologist, 49, 3, 440-5.

Cutchin, M. 2003. The process of mediated aging-in-place: a theoretically and empirically based model. Social Science and Medicine, 57, 6, 1077-90.

Degnen, C. 2005. Relationality, place, and absence: a three-dimensional perspective on social memory. The Sociological Review, 53, 4, 729-44

Degnen, C. 2012. Ageing Selves and Everyday Life in the North of England: Years in the Making. Manchester: Manchester University Press.

Degnen, C. 2013. 'Knowing', absence and presence: the spatial and temporal depth of relations. Environment and Planning D: Society and Space, 31, 3, 554-70.

Edwards, J. 200o. Born and Bred: Idioms of Kinship and New Reproductive Technologies in England. Oxford University Press, Oxford.

Edwards, J. 1998. The need for a 'bit of history': place and past in English identity. In Lovell, N. (ed.), Locality and Belonging. Routledge, London, 147-67.

Fentress, J. and Wickham, C. 1992. Social Memory. Blackwell, Oxford.

Gordillo, G. 2004. Landscapes of Devils: Tensions of Place and Memory in the Argentinean Chaco. Duke University Press, Durham, North Carolina.

Gilleard, C., Hyde, M. and Higgs, P. 2007. The impact of age, place, aging in place, and attachment to place on the well-being of the over 5 os in England. Research on Aging, 29, 6, 590-605.

Halbwachs, M. 1925. Les Cadres Sociaux de la Mémorie. Alcan, Paris.

Hamby, P. and Wyatt, S. 1997. Honest Dodworth 2. Dodworth Publications, Dodworth, UK.

Kearns, R. and Andrews, G. 2005. Placing ageing: positionings in the study of older people. In Andrews, G. and Phillips, D. (eds), Ageing and Place: Perspectives, Policy, Practice. Routledge, London, 13-23.

Kellaher, L., Peace, S. and Holland, C. 2004. Environment, identity and old age quality of life or a life of quality? In Walker, A. and Hennessy, C. (eds), Growing Older: Quality of Life in Old Age. Open University Press, Maidenhead, UK. 
Kontos, P. 2004. Ethnographic reflections on selfhood, embodiment and Alzheimer's disease. Ageing $\mathcal{E} \mathcal{F}$ Society, 24, 6, 829-49.

Kontos, P. 2005. Embodied selfhood in Alzheimer's disease: rethinking personcentred care. Dementia, 4, 4, 553-70.

Lambek, M. 1996. Past imperfect: remembering as moral practice. In Antze, P. and Lambek, M. (eds), Tense Past: Cultural Essays in Trauma and Memory. Routledge, London, 235-54.

Laws, G. 1994. Contested meanings, the built environment and aging in place. Environment and Planning A, 26, 1 1, 1787-802.

Laws, G. 1995. Embodiment and emplacement: identities, representation and landscape in Sun City retirement communities. International Journal of Aging and Human Development, 4o, 4, 253-80.

Laws, G. 1997. Spatiality and age relations. In Jamieson, A., Harper, S. and Victor, C. (eds), Critical Approaches to Ageing and Later Life. Open University Press, Buckingham, UK, 90-10o.

Lawton, M. P. 1983. Environment and other determinants of well-being in older people. The Gerontologist, 23, 4, 349-57.

Lawton, M. P. 1985. The elderly in context: perspectives from environmental psychology and gerontology. Environment and Behaviour, 1 7, 4, $5^{\mathrm{O} 1-19}$.

Lawton, M. P. 1986. Environment and Aging. Second edition, Center for the Study of Aging, Albany, New York.

Massumi, B. 2002. Parables for the Virtual: Movement, Affect, Sensation. Duke University Press, Durham, North Carolina.

Massey, D. 1994. Space, Place and Gender. University of Minnesota Press, Minneapolis, Minnesota.

McHugh, K. 2006. Ageing and place: perspectives, policy, practice. The Professional Geographer, 58, 4, 493-5.

McHugh, K. and Mings, R. 1996. The circle of migration: attachment to place in aging. Annals of the Association of American Geographers, 86, 3, 530-50.

Melion, W. and Küchler, S. 1991. Introduction: memory, cognition, and image production. In Küchler, S. and Melion, W. (eds), Images of Memory: On Remembering and Representation. Smithsonian Press, Washington DC, $1-46$.

Misztal, B. 2003. Theories of Social Remembering. Open University Press, Maidenhead, UK.

Olick, J. and Robbins, J. 1998. Social memory studies: from 'collective memory' to the historical sociology of mnemonic practices. Annual Review of Sociology, 24, $105-40$.

Peace, S., Holland, C. and Kellaher, L. 2005. Making space for identity. In Andrews, G. and Phillips, D. (eds), Ageing and Place: Perspectives, Policy, Practice. Routledge, London, 188-204.

Peace, S., Wahl, H., Mollenkopf, H. and Oswald, F. 2011 . Environment and ageing. In Katz, J., Peace, S. and Spurr, S. (eds), Adult Lives: A Life Course Perspective. Policy Press, Bristol, UK, 131-41.

Phillips, J., Walford, N. and Hockey, A. 2011 . How do unfamiliar environments convey meaning to older people? Urban dimensions of placelessness and attachment. International Journal of Ageing and Later Life, 6, 2, 73-102.

Phillipson, C. 2007. The 'elected' and the 'excluded': sociological perspectives on the experience of place and community in old age. Ageing E Society, 27, 3, 32 1-42.

Rowles, G. 1978. Prisoners of Space. Westview Press, Boulder, Colorado.

Rowles, G. 1983a. Geographical dimensions of social support in rural Appalachia. In Rowles, G. and Ohta, R. (eds), Aging and Milieu: Environmental Perspectives on Growing Old. New York, Academic Press, 111 1-3o. 
Rowles, G. $1983 b$. Place and personal identity in old age: observations from Appalachia. Journal of Environmental Psychology, 3, 4, 299-313.

Rubinstein, R. and Parmelee, P. 1992. Attachment to place and the representation of the life course by the elderly. In Altman, I. and Low, S. (eds), Place Attachment. New York, Springer, 139-64.

Savage, M., Bagnall, G. and Longhurst, B. 2005. Globalization and Belonging. Sage, London.

Seamon, D. 1980. Body-subject, time-space routines, and place-ballets. In Buttimer, A. and Seamon, D. (eds), The Human Experience of Space and Place. St Martin's Press, New York, 148-65.

Stewart, K. 1996. A Place on the Side of the Road: Cultural Poetics in an 'Other' America. Princeton University Press, Princeton, New Jersey.

Strathern, M. 1982. Kinship at the Core: An Anthropology of Elmdon, a Village in NorthWest Essex in the Nineteen-sixties. Cambridge University Press, Cambridge.

Thrift, N. 1999. Steps to an ecology of place. In Massey, D., Allen, J. and Sarre, P. (eds), Human Geography Today. Polity Press, Cambridge, 295-323.

Yarrow, T. 2011 . Kinship and the core house: contested ideas of family and place in a Ghanaian resettlement township. In Edwards, J. and Petrovic-Šteger, M. (eds), Recasting Anthropological Knowledge: Inspiration and Social Science. Cambridge University Press, Cambridge, 88-105.

Accepted 7 May 2OI5; first published online 24 June 2015

Address for correspondence:

Cathrine Degnen, School of Geography, Politics and Sociology, Newcastle University, Claremont Bridge Building, 5 th Floor,

Newcastle upon Tyne NE 17 RU, UK

E-mail: cathrine.degnen@ncl.ac.uk 